\title{
Effects of vermicompost and urea on the seed germination and growth parameters of Vigna mungo L. and Vigna radiata L. Wilzek
}

\author{
Sanchita Bhattacharya* \\ Department of Botany, M.B.B. College, Agartala-799004 (Tripura West), India \\ Sourav Debnath \\ Department of Botany, M.B.B. College, Agartala-799004 (Tripura West), India \\ Sanjit Debnath \\ Mycology and Plant Pathology Laboratory, Department of Botany, Tripura University \\ Suryamaninagar-799022 (Tripura), India \\ Ajay Krishna Saha \\ Mycology and Plant Pathology Laboratory, Department of Botany, Tripura University, \\ Suryamaninagar-799022 (Tripura), India
}

*Corresponding authors. E-mail: sanchita270873@rediffmail.com

\begin{abstract}
Growth attributes of Vigna mungo and Vigna radiata crop influenced by level and type of fertilizers. The present study was carried out to evaluate and compare the effects of organic (vermicompost) and inorganic (urea) fertilizers on the germination percentage and seedling growth of $V$. radiata (Green gram) and $V$. mungo (Black gram). Fresh weight and dry weight of tested plant samples at $10^{\text {th }}$ days of growth stage were also determined. Vermicompost was used as organic fertilizer and urea as inorganic fertilizer. Experimental results showed that vermicompost and urea both has positive effect on seedling growth parameters of $V$. mungo and $V$. radiata [average root length $(6.1 \mathrm{~cm}$ and $6.7 \mathrm{~cm})$ ] , shoot length $(6.5 \mathrm{~cm}$ and $8.3 \mathrm{~cm})$, leaf area $(312.2 \mathrm{sq} . \mathrm{cm}$ and $334.1 \mathrm{sq} . \mathrm{cm}]$ as compared to control set [average root length $(4.4 \mathrm{~cm}$ and $4.3 \mathrm{~cm})$ ], shoot length $(6 \mathrm{~cm}$ and $5.9 \mathrm{~cm})$, leaf area (282.7 sq.cm and 305.5 sq.cm). But urea exerts negative effect on seed germination percentage in $V$. mungo and $V$. radiata $(58 \%$ and $50 \%)$ as compared to control $(77 \%)$. Vermicompost exhibited better result in above parameters in comparison to urea. $V$. mungo showed increased value in comparison considering $V$. radiata in case of organic, inorganic fertilizer treated as well as control sets. As composition of locally available fertilizers is unknown, the application of these fertilizers for improving germination percentage and growth parameters of tested crop need to be evaluated. Present work may provide the suggestive approach for usage of these tested fertilizers in field level trial.
\end{abstract}

Keywords: Agricultural Practices, Biofertilizer, Organic Fertilizers, Seedling Growth

\section{Article Info}

DOI:10.31018/jans.v11i2.2052

Received: March 29, 2019

Revised: April 24, 2019

Accepted: May 1, 2019

\section{How to Cite}

Bhattacharya, S. et al. (2019). Effects of vermicompost and urea on the seed germination and growth parameters of Vigna mungo L. and Vigna radiata L. Wilzek. Journal of Applied and Natural Science,11(2): $321-326$ https:// doi.org/10.31018/ jans.v11i2.2052

\section{INTRODUCTION}

Germination of seed is the principal requirement of growth of the plants and influenced by various physical and chemical parameters either present in the surrounding environment or may be added into the substratum. Amount of nutrients present in the soil influence the quality of yield of the crop. Soil additives used to improve nutrient quantity and quality of the soil are usually chemical or organic compounds. The mineral fertilizers provide only plant nutrients in the soils but unable to improve soil health significantly (Chattopadhyay, 2005). Application of excessive inorganic or chemical fertilizers deteriorates chemical, physical, and biological properties of soil (Mahajan et al., 2008). Indiscriminate use of chemical fertilizers decreases soil fertility level. Apart from that toxic sub- stances accumulate within the vegetables and generate negative effects in humans and animals (Savci, 2012). On the other hand organic fertilizers increase supply of nutrients, soil nutrient accessibility and soil microbial action (Chand et al., 2006). Vermicompost as a organic fertilizer reported to contain a number of mineral nutrients, soil enzymes and microbes (Domínguez, 2004) and reported to improve seed germination, seedling vigor, and plant productivity rather than inorganic mineral nutrient (Gopalakrishnan et al., 2012). Moreover, as soil additives, vermicompost provide required amounts of nutrient, increase water holding capacity of soil and cation exchange capacity thus reduce the use of mineral fertilizers in cultivation of crop (Tejada and Gonzaler, 2009). Vermicomposts contain bioactive substances like plant growth regulators (Arancon et al., 2005). 
Some plant growth regulators like indole acetic acid, gibberellins and cytokinins extracted from aqueous solutions of vermicomposts and have their significant effects on plant growth (Atiyeh et al., 2002).

Effect of organic and inorganic fertilizer in germination rate, growth parameters, yield attributes and nutritional status of different crops were evaluated by several researchers. The vermicompost increases the yield of rice and thus can be a substitute to chemical fertilizer to some extent (Sharma et al., 2008). It has also been found that in case of rice and lentil the application of vermicompost showed better result in terms of improving soil physical and chemical properties and increased grain yield and productivity in comparison to chemical fertilizers (Karmakar et al., 2015). A significant increase and the maximum dry matter, number of pods, pod yield (g) and seed yield (g) per plant of black gram was observed when vermicompost incorporated with the PSB seed inoculation (Kadam et al., 2014). Plant growth, nodulation and yield of black gram [Vigna mungo (L.) Hepper] in different soil amendment was evaluated. It was observed that, nodule number was significantly increased by addition of either of the two strains of nitrogen fixing Bradyrhizobium japonicum (TAL- 102 and MN-S) strains in NPK treated and un-amended soils. (Javaid, 2009). Effects of vermicompost on Bengal gram (Cicer arietinum L.) var. RSG-896 were studied. Plants were harvested at three stages i.e. pre-flowering, peak-flowering and post-flowering stages. Increased levels of vermicompost level increased root length, shoot length, root dry weight, shoot dry weight, and total dry weight (Shrimal and Khan, 2017). Similarly application of aqueous extract of vermicompost reported to improve plant health, crop yield, and nutritive quality in pakchoi (Pant et al., 2009). Urea was used as fertilizer to evaluate the growth parameters like germination, survival, seedling height and root/shoot ratio were studied on the seeds of Pisum sativum, Vigna radiata and Vigna catjang with high nutritional and medicinal value (Ramteke et al., 2013).

Green gram (V. radiata L.) locally known as "moong" is one of the important and widely cultivated crop in India, and usually cultivated in arid and semi arid region. Black gram ( $V$. mungo L.) is also one of the important pulse crops grown in India. This is also grown as a cover crop as well as catch crop due to short duration. Pulses are the cheapest source of quality protein for human being. These also known to increase soil fertility by fixing atmospheric nitrogen in soil symbiotically and improve the productivity of succeeding crop. Excessive and indiscriminate use of nutrients by farmers is the most vital limiting factor for crop productivity especially in pulses. Therefore, comparison of the effects of vermicompost (organic) and urea (inorganic) fertilizers on the germination and growth parameters of $V$. radiata (Green gram) and $V$. mungo (Black gram) are necessary to optimize the fertilizer application as soil amendments.

\section{MATERIALS AND METHODS}

Experiment was carried out during the month of February to May in the year of 2017-2019.

Plant material: Certified homozygous seeds of Black gram (Vigna mungo L.var PU-31) and Green gram (Vigna radiata L. Wilzek var PDM139) were procured from the Seed Testing Laboratory of State Agricultural Centre, A.D. Nagar, Agartala, Tripura, India, for the present study. Homozygous seeds were preferred over heterozygous type to minimize the phenotypic variation in respect of morphological features. Vermicompost was used as organic fertilizer and Urea as inorganic fertilizer. Vermicompost and urea (composition unknown, locally available) were procured from the local market.

Preparation of soil: Substratum was prepared for sowing of seeds by mixing of soil and sand in 3:1 ratio for different fertilizer treated sets as well as for control set.

Experimental sets: Control set: Soil contained no fertilizer. Black gram Control (BGC) and Green gram Control (GGC) were taken as control.

Vermicompost (Organic fertilizer) treated sets: $4 \mathrm{gm}$ of soil contained $1 \mathrm{gm}$ of vermicompost. Black gram vermicompost treated (BGO) and Green gram vermicompost treated (GGO) were taken as Vermicompost treated sets.

Urea (Inorganic fertilizer): $0.5 \mathrm{gm}$ of inorganic fertilizer was spread over the $10 \mathrm{gm}$ soil. Black gram Urea treated $(\mathrm{BGI})$ and Green gram Urea treated (GGI) were taken as Urea treated sets.

The fertilizers were used only for the preparation of the seed beds after that no fertilizers were used.

Sowing of seeds: Germination trays were used for seed sowing. Pre-soaked seeds were sown in the prepared soil at a depth of 0.5 to $1.0 \mathrm{~cm}$. 100 seeds were sown ( 2 replicates of 50 seeds) for each experimental sets. Mist spraying bottle was used for regular watering.

Germination percentage and other growth parameters: The shoot and root length were measured on $5^{\text {th, }} 7^{\text {th }}$ and $10^{\text {th }}$ day. Germination percentage was calculated on the basis of data collected on $10^{\text {th }}$ day using following formula (Eq. 1) (Javed and Panwar, 2013).

Germination $(\%)=$ Number of seeds germinated $/$ Number of seeds put for germination $\times 100$

After $10^{\text {th }}$ day of sowing, plants were carefully pulled out of the soil and fresh weight of the samples of each experimental set. The dry weights of the samples were also recorded.Prior to the germination experiment seed sample lots were grown 
in pot culture treated separately with different concentrations of urea solutions for seven days. Adverse effects induced by urea solutions on morphology of tested plant samples were observed to determine suitable concentrations level of urea for treating experimental sets (Dhanalakshmi et al., 2014).

\section{RESULTS AND DISCUSSION}

Experimental results of present study revealed that maximum germination percentage was observed in V. mungo L.var. PU-31 (94\%) followed by $V$. radiata L.var. PDM-139 $(73 \%)$ in case of organic fertilizer (vermicompost) treated experimental sets. However, it was evident that among two crops, highest germination percentage was achieved by $V$. mungo. Minimum percentage of germination was recorded in inorganic fertilizer (urea) treated set of $V$. mungo (58\%) followed by $V$. radiata $(50 \%)$. Present findings also revealed that control sets exhibited better germination percentage than inorganic fertilizer treated set in case of both the crops (Table 1). It was found that, in $V$. mungo maximum seed germination percentage was observed for vermicompost treated soil (Javed and Panwar, 2013) which substantiated the present experimental results.

Regarding growth parameters of $V$. mungo and $V$. radiata growing under different experimental conditions, results also showed that maximum root length $(6.1 \mathrm{~cm}$ and $6.7 \mathrm{~cm})$, shoot length $(6.5 \mathrm{~cm}$ and $8.3 \mathrm{~cm})$ and average leaf area $(312.2 \mathrm{sq} . \mathrm{cm}$

Table 1. Germination percentage of $V$. mungo and $V$. radiata.

\begin{tabular}{|c|c|c|c|c|c|c|}
\hline Tested Samples & & V. mungo & & & V. radiata & \\
\hline $\begin{array}{l}\text { Germination Per- } \\
\text { centage }\end{array}$ & $\begin{array}{c}\text { Control } \\
77 \%\end{array}$ & $\begin{array}{c}\text { Inorganic } \\
58 \%\end{array}$ & $\begin{array}{c}\text { Organic } \\
94 \%\end{array}$ & $\begin{array}{c}\text { Control } \\
66 \%\end{array}$ & $\begin{array}{c}\text { Inorganic } \\
50 \%\end{array}$ & $\begin{array}{c}\text { Organic } \\
73 \%\end{array}$ \\
\hline
\end{tabular}

Table 2. Seedling growth parameters of $V$. mungo and $V$. radiata.

\begin{tabular}{|c|c|c|c|c|c|c|c|c|c|}
\hline \multirow{2}{*}{$\begin{array}{l}\text { Different } \\
\text { treatments }\end{array}$} & \multicolumn{3}{|c|}{$\begin{array}{l}\text { Average length of root } \\
(\mathrm{cm})\end{array}$} & \multicolumn{3}{|c|}{$\begin{array}{c}\text { Average length of shoot } \\
(\mathrm{cm})\end{array}$} & \multicolumn{3}{|c|}{$\begin{array}{l}\text { Average Leaf Area } \\
\text { ( Square } \mathrm{mm} \text { ) }\end{array}$} \\
\hline & 5th Day & 7th Day & 10th Day & 5th Day & 7th Day & 10th Day & 5th Day & 7th Day & 10th Day \\
\hline $\begin{array}{l}\text { V. mungo } \\
\text { (Control) }\end{array}$ & 3.3 & 3.8 & 4.4 & 4.0 & 5.3 & 6 & 195.6 & 203.4 & 282.7 \\
\hline $\begin{array}{l}\text { V. mungo } \\
\text { (Inorganic) }\end{array}$ & 4.6 & 5.0 & 5.4 & 4.7 & 5.4 & 6.1 & 199.5 & 210.0 & 299.5 \\
\hline $\begin{array}{l}\text { V. mungo } \\
\text { (Organic) }\end{array}$ & 5.4 & 5.9 & 6.1 & 5.1 & 5.7 & 6.5 & 212.6 & 258.9 & 312.2 \\
\hline $\begin{array}{l}\text { V. radiata } \\
\text { (Control) }\end{array}$ & 3.7 & 4.0 & 4.3 & 4.5 & 5.1 & 5.9 & 194.2 & 237.6 & 305.5 \\
\hline $\begin{array}{l}\text { V. radiata } \\
\text { (Inorganic) }\end{array}$ & 5.3 & 5.5 & 6.3 & 5.0 & 5.3 & 6.4 & 201.6 & 255.5 & 310.8 \\
\hline $\begin{array}{l}\text { V. radiata } \\
\text { (Organic) }\end{array}$ & 5.6 & 6.2 & 6.7 & 5.5 & 6.1 & 8.3 & 213.8 & 275.3 & 334.1 \\
\hline
\end{tabular}

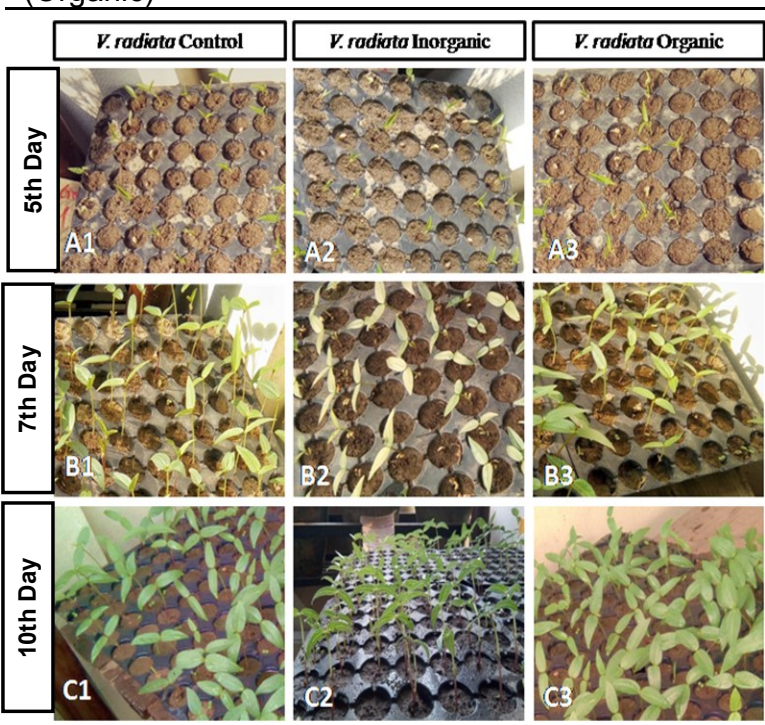

Fig. 1. Showing plant growth on three different (control, inorganic and organic) treatments of $\mathrm{V}$. radiata after 5 days $(A 1, A 2, A 3), 7$ days $(B 1, B 2, B 3)$ and 10 days $(C 1, C 2, C 3)$.

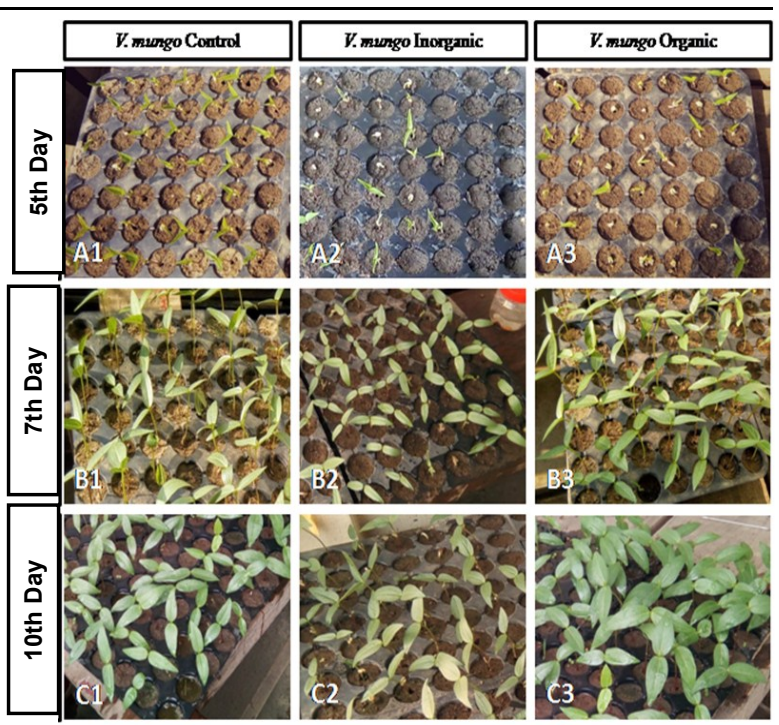

Fig. 2. Showing plant growth on three different (control, inorganic and organic) treatments of $\mathrm{V}$. mungo after 5 days $(A 1, A 2, A 3), 7$ days $(B 1, B 2, B 3)$ and 10 days $(C 1, C 2, C 3)$. 

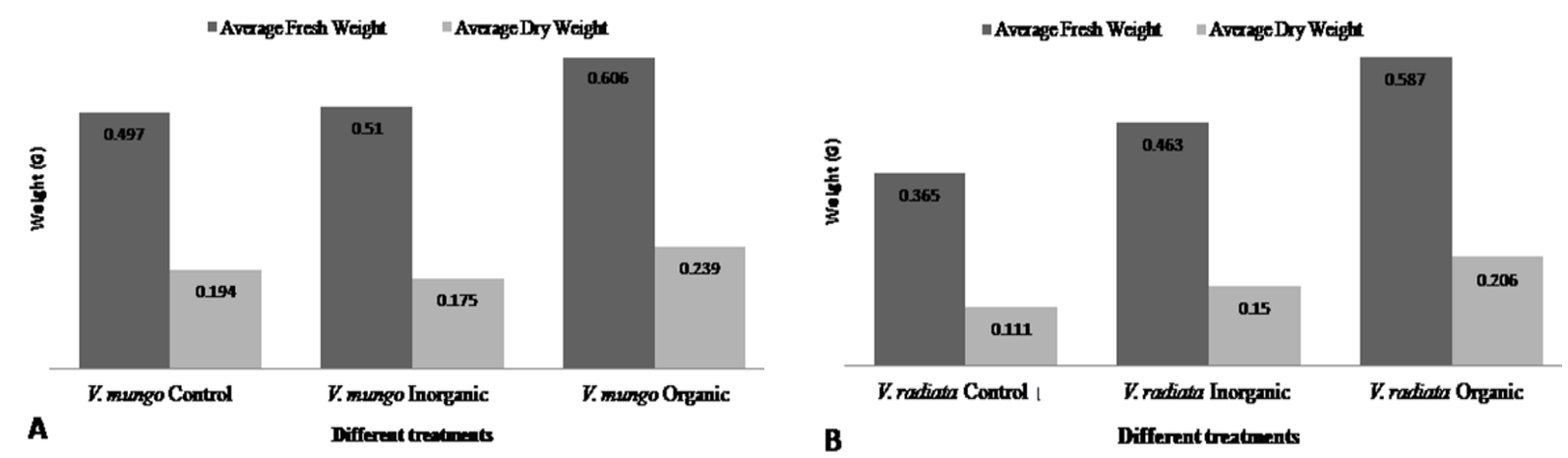

Fig. 3. Fresh and dry weight of A. V. mungo, B. V.radiata plants in organic fertilizer and inorganic fertilizer treated soil in pot culture experiment.

and 334.1 sq.cm) were obtained in case of seed sown in organic fertilizer treated sets followed by inorganic fertilizer treated batch (Fig. 1 and 2). Control sets for both the crops exhibited lowest vales in respect of growth parameters (Table 2). Among both the crops, it was observed that $V$. radiata exhibited better results over $V$. mungo, when grown in vermicompost as well as urea treated soil in respect to average root and shoot length and leaf area (Table 2). Maximum average dryand fresh weights were recorded in organic fertilizer applied experimental sets of both the crops. However, V. mungo showed increased values in comparison considering $V$. radiata in case of organic, inorganic fertilizer treated as well as control sets (Fig. 3).

For $V$. mungo lowest average dry weight of plant sample was obtained in inorganic fertilizer treated sets, while for $V$. radiata it was lowest value recorded in control set (Fig. 3).

Percentage of seed germination and seedling length and growth parameters such as shoot length, root length, number of leaves per plant and leaf area of tomato increased (Lycopersicum esculentum) when seeds grown in vermicompost amended soil as compared to other treated soil (Eswaran and Mariselvi, 2016) which correlated with present findings. Experiment on effects of organic amendments and chemical fertilizer on growth of cowpea revealed that all five treatments of organic fertilizers showed positive effect on root length, shoot length, fresh weight and dry weight of tested plant in comparison to treatment with chemical fertilizer which also supported present experimental findings (Badar et al., 2015). The experimental results revealed that application of organic fertilizer (vermicompost) improves seed germination rate and enhanced growth of tested plants. These may be due to that vermicompost provides mineral nutrients in available forms to plants (Grantina-levina et al., 2015). These plant growth-promoting activity of vermicomposts usually for the high content of humic compounds (Muscolo et al., 1999). Significant variation in the plant height of rice was observed, when the field was incorporated with different doses of vermicompost. The present experimental results in respect to shoot and root length also supported increased value in vermicompost treated sets. This may be due to the increased soil moisture content, soil porosity by vermicompost application (Mahmud et al., 2016). Present experimental results revealed that application of vermicompost improve average root and shoot length as well as average leaf area of both the tested plant over control set. These can be correlated with earlier observations. Use of vemicompost and FYM at the rate of $5 \mathrm{t} / \mathrm{ha}$ significantly improve plant height, root nodules/plant, pods/plant and grains/pod, over control sets with no organic manure (Ghanshyam et al., 2010). Three different concentrations $(10 \%, 20 \%$ and $30 \%)$ of vermiwash were used to evaluate its growth promoting effects considering the seed germination and seedling growth of $V$. radiata and $V$. mungo. Germination percentage increased with increasing concentration of vermiwash in $V$. radiata and in $V$. mungo. Hypocotyls length increased in $V$. radiata ascompare to $V$. mungo whereas, radical length was more in $V$. mungo (Jaybhaye and Bhalerao, 2015). Moreover, results obtained from present study also supported by findings where evaluation of responses of green gram ( $V$. radiata L.) to different levels of phosphorus and organic liquid fertilizer revealed that all most all the yield attributes such as number of pods per plant, number of seeds per pod and pod length were influenced by different treatments of organic liquid fertilizer (Patel et al., 2017). In a study to find out the effect of different fertilizers, it was observed that in case of Pisum sp. and Cicer sp. plant grown in vermicompost pre -treated soil showed maximum increase in morphological parameters such as root length, shoot length, number of root branches, number of stem branches, number of leaves, number of flowers, number of pods and number of root nodules in four months sampling in comparison to control set (Sinha et al., 2010) which also supported the pre- 
sent findings.

\section{Conclusion}

Present experimental results showed that the applications of vermicompost induced better germination rate and increased level of growth parameters (average shoot, root length and leaf area) in both the tested samples. Therefore, it may be stated that for $V$. mungo and $V$. radiata organic fertilizers like, vermicompost, may be a better alternative to inorganic fertilizer for improving germination, growth parameter and yield attributes. These experimental results can be applied at larger field levels to improve yield attribute of crop plants for safe and sustainable agricultural practices However, extensive field trials may be needed to conclude that organic fertilizer (vermicompost) should be preferred over inorganic fertilizer (urea) in agricultural practices.

\section{ACKNOWLEDGEMENTS}

The first and second authors are grateful to the Head, Department of Botany, M.B.B. College, Tripura for providing laboratory facilities.

\section{REFERENCES}

1. Arancon, N.Q., Galvis, P.A. and Edwards, C.A. (2005). Suppression of insect pest populations and damage to plants by vermicomposts. Bioresource Technology,96:1137-1142. DOI: 10.1016/ j.biortech.2004.10.004

2. Atiyeh, R.M., Lee, S., Edwards, C.A., Arancon, N.Q. and Metzger, J.D. (2002). The influence of humic acids derived from earthworm-processed organic wastes on plant growth. Bioresource Technology,84:7-14. doi.org/10.1016/S0960-8524(02)00017-2

3. Badar, R., Khan, M., Batool, B. and Shabbir, S. (2015). Effects of organic amendments in comparison with chemical fertilizer on cowpea growth. International Journal of Applied Research, 1(5): 66-71.

4. Chand, S., Anwar, M. and Patra, D.D. (2006).Influence of long-term application of organic and inorganic fertilizer to build up soil fertility and nutrient uptake in mint-mustard cropping sequence. Communications in Soil Science and Plant Analysis, 37: 63-76.doi.org/10.1080/00103620500408704

5. Chattopadhyay, G.N. (2005). Vermicomposting as a biotechnological tool form recycling organic wastes. In: Ghosh TK, Chakrabarti T, Tripathi G (eds) Biotechnology in environmental management, vol 1. A.P.H. Publishing Corporation, New Delhi, pp135145.

6. Domínguez, J. (2004). State of the art and new perspectives on vermicomposting research. In: Earthworm ecology (Ed.):C.A. Edwards, 2nd edition, CRC Press, Boca Raton, pp 401-424.

7. Eswaran, N. and Mariselvi, S.(2016). Efficacy of Vermicompost on growth and yield parameters of $L y c o-$ persicum esculentum(Tomato).International Journal of Scientific and Research Publications, 6(1):95-108.

8. Ghanshyam, Kumar, R. and Jat, R.K. (2010). Productivity and soil fertility as affected by organic manures and inorganic fertilizers in greengram (Vigna radiata L.)- wheat (Triticum aestivumL.) sys- tem. Indian Journal of Agronomy, 55(1):16-21.

9. Grantina-levina, L., Nikolajeva, V., Rostoks, N., Skrabule, I., Zarina, L.,Pogulis, A., andlevinsh, G. (2015). Impact of green manure and vermicompost on soil suppressiveness, soil microbial populations and plant growth in conditions of organic agriculture of Northern temperate climate. In: Meghvansi M.K., Varma A. (eds.). Organic Amendments and Soil Suppressiveness in Plant Disease Management. Springer International Publishing, Switzerland, pp $381-$ 399.DOI: 10.1007/978-3-319-23075-7 18

10.Gopalakrishnan, S., Humayun, P., Vadlamudi, S., Vijayabharathi, R., Bhimineni, R.K., and Rupela, O. (2012). Plant growth-promoting traits of streptomyces with biocontrol potential isolated from herbalvermicompost. Biocontrol Science and Technology, 22 (10):1199-1210.

https:// doi.org/10.1080/09583157.2012.719151

11.Jaybhaye, M.M. and Bhalerao, S.A. (2015). Influence of Vermiwash on Germination and Growth Parameters of Seedlings of Green gram (Vigna radiata L.) and Black gram (Vigna mungo L.).International Jour-

nal of Current Microbiologyand Applied Sciences, 4 (9): 634-643.

12.Javaid, A.(2009). Growth, Nodulation \& Yield of Black Gram [Vigna mungo (L.) Hepper] as influenced by bio fertilizers and soil amendments. African Journal of Biotechnology, 8(21):5711-5717. https:// doi.org/10.4314/ajb.v8i21.66043

13.Javed, S. and Panwar, A.(2013). Effect of biofertilizer, vermicompost and chemical fertilizer on different biochemical parameters of Glycine max and Vigna mungo.Recent Research in Science and Technology, $5(1): 40-44$.

14.Kadam, S.R., Kalegore, N.K. and Patil, S.R. (2014). Influence of phosphorus, vermicompost and PSB on yield attributes, seed yield and quality of black gram. Advance Research Journal of Crop Improvement,5 (1):7-10.

15.Karmakar, S., Adhikary, M., Gangopadhyay A.and Brahmachari, K. (2015). Impact of Vermicomposting in Agricultural Waste Management vis-à-vis Soil Health Care. Journal of Environmental Science and Natural Resources,8(1): 99-104.https:// doi.org/10.3329/jesnr.v8i1.24680

16. Mahajan A, Bhagat RM, and Gupta RD. (2008). Integrated nutrient management in sustainable ricewheat cropping system for food security in India. SAARC Journal of Agriculture, 6(2):149-163.

17.Mahmud, A.J., Shamsuddoha, A.T.M. and Haque, M.N. (2016). Effect of Organic and Inorganic Fertilizer on the Growth and Yield of Rice (Oryza sativa L). Natural Science, 14(2):45-54. https://doi.org/10.7537/ marsnsj14021607.

18.Muscolo, A., Bovalo, F., Gionfriddo, F. andNardi, S. (1999). Earthworm humic matter produces auxin-like effects on Daucus carotacell growth and nitrate metabolism. Soil Biology and Biochemistry, 31(9):13031311. https://doi.org/10.1016/S0038-0717(99)000498

19.Pant, A., Radovich, T.J.K., Hue, N.V., Talcott, S.T. and Krenek, K.A. (2009). Vermicompost extracts influence growth, mineral nutrients, phytonutrients and antioxidant activity in pakchoi (Brassica rapa cv. Bonsai, Chinensis group) grown under vermicompost and chemical fertiliser. Journal of the Science of 
Food and Agriculture, 89:2383-2392. https:// doi.org/10.1002/jsfa.3732

20.Patel, H.B., Shah, K.A., Barvalya, M.M. and Patel, S.A. (2017). Response of green gram (Vigna radiata L.) to different level of Phosphorus \& organic liquid fertilizer. International Journal of Current Microbiology and Applied Sciences, 6(10):3433-3451. https:// doi.org/10.20546/ijcmas.2017.610.406

21.Ramteke, A.A., Narwade, M.L., Gurav, A.B, Chavan, S.P. and Wandre, A.G. (2013).Study of germination effect of fertilizers like urea NPK and biozyme on some vegetable plants. Der Chemica Sinica,4(3):2226.

22.Sharma, D.K., Prasad, K. and Yadav, S.S. (2008). Effect of integrated nutrient management on the performance of dwarf scented rice (Oryza sativa L.) growth in rice wheat sequence. International Journal of Agricultural Sciences, 4(2):660-662.

23.Savci, S. (2012). Investigation of Effect of Chemical Fertilizers on Environment. APCBEE Procedia, 1:287 -292. https://doi.org/10.1016/j.apcbee.2012.03.047
24.Shrimal, P. and Khan, T.I. (2017).Studies on the Effects of Vermicompost on Growth Parameters and Chlorophyll Content of Bengal Gram (Cicer arietinum L.) var. RSG-896. IOSR Journal of Environmental Science, Toxicology and Food Technology,11(5):1216. https://doi.org/ 10.9790/2402-1105031216

25.Sinha, J., Biswas, C.K. Ghosh, A. and Saha, A. (2010). Efficacy of vermicompost against fertilizers on Cicer and Pisum and on population diversity of N2 fixing bacteria. Journal of Environmental Biology, 31 (3):287-292.

26.Tejada M, and Gonzaler JL. (2009). Application of two vermicompost on a rice crop: effects on soil biological properties and rice quality and yield. Agronomy Journal, 101(2):336-344. https://doi.org/10.2134/ agronj2008.0211.

27.Dhanalakshmi V., Remia K. M., Shanmugapriyan R., and Shanthi K. (2014). Impact of addition of Vermicompost on Vegetable Plant Growth. International Research Journal of Biological Sciences, 3(12):56-61 